\title{
Chromatographically purified Vi-capsular polysaccharide antigen for vaccination against Typhoid fever
}

\author{
I.V. Ankudinov, M.E. Golovina, V.L. L’vov, N.P. Vaneeva, I.C. Verner, S.I. Yolkina, P.G. Aparin
}

\begin{abstract}
Abstrak
Kami telah mendapatkan antigen-Vi dengan tingkat kualitas kromatografi dalam bentuk tidak terdenaturasi yang memberikan proteksi efektif terhadap infeksi demam tifoid. Antigen-Vi yang kemurniannya tinggi diisolasi dengan filtrasi-gel dan menggunakan metode pengolahan paling ringan dengan mengurangi sejumlah prosedur yang menggunakan bahan kimia. Struktur molekul antigen-Vi termasuk yang paling aktif secara imunologik, group O-Ac-dan $\mathrm{COO}^{-}$- tidak berubah pada pengolahan yang dilakukan dan telah dibuktikan dengan data Spektroskop NMR. Berat molekul maksimum tertinggi dan fraksi imunogenik antigen Vi tersebut digunakan dalam vaksin $\left(K d<0,25\right.$ pada kromatografi dengan sepharose 4B-CL). Antigen Vi sejenis digunakan sebagai komponen utama vaksin tifoid VIANVAC ${ }^{\circledR}$. Dalam tes laboratorium antigen Vi memberikan proteksi efektif yang tinggi pada mencit terhadap infeksi galur virulen S. typhi Ty2, menurut prosedur WHO, FDA untuk challenge test demam tifoid. Imunisasi beberapa kelompok manusia pada percobaan klinik terkontrol menginduksi respon imun anti Vi yang kuat terdeteksi dengan Indirect heamagglutination atau tes ELISA. Pada kelompok yang diimunisasi dapat dideteksi IgG, IgM dan bahkan IgA antibodi spesifik Vi. Kekebalan aktif pada manusia terbentuk 2 - 3 minggu setelah vaksinasi, bersamaan dengan pembentukan respon imun humoral. Percobaan preklinik dan klinik memastikan tingkat keamanan yang tinggi vaksin ini. Hanya tercatat efek samping rasa sakit lokal, dan efek samping sistemik jarang terjadi. Data vaksinasi yang terbaru dengan vaksin antigenVi yang dimurnikan dengan kromatografi pada kejadian luar biasa demam tifoid di Tajikistan akan dipresentasikan.
\end{abstract}

\begin{abstract}
We have obtained chromatography grade quality Vi-antigen in non-denatured form which provide effective protection against typhoid fever infection. Highly purified Vi-antigen is isolated by gel-filtration with use of most mild methods of treatment and lowered number of procedures with chemical agents involved. Vi-antigen molecule structure including most immunologically active O-Ac-and $C O O$ - groups doesn't change under such treatment and have been verified by NMR-spectroscopy data. Maximal high molecular weight and immunogenic fractions of $V i$-antigen are used in vaccine $(K d<0.25$ under chromatography on Sepharose $4 B$-CL). Such Vi-antigen is used as main component of VIANVAC ${ }^{\Theta}$ typhoid vaccine. In laboratory tests Vi-antigen provides highly effective protection of mice against infection by virulent strain S. typhi Ty2 according WHO, FDA regulations for typhoid fever challenge test. Immunisation of human contingents under the controlled clinical trials induced powerful anti-Vi immune response which was detected in indirect heamagglutination or ELISA tests. IgG, IgM and even detectable quantity of IgA Vi-specific antibodies are registered in immunized persons. Active immunity in humans forms in 2-3 weeks after the vaccination simultaneously with the development of humoral immune response. Preclinical and clinical trials confirm high safety of preparation. Local side reactions were registered as only painfulness, common side reaction are rare. The recent vaccination data by chromatographically purified Vi-antigen vaccine under typhoid fever outbreak in Tajikistan will be presented.
\end{abstract}

\section{INTRODUCTION}

Typhoid fever is still a common disease, causing significant morbidity and mortality in countries that have not yet achieved satisfactory control of drinking water, food and sewage disposal.

Control of typhoid fever may be aided by immunization, but widespread protection by this method has not been achieved for various reasons, including the limitation and insufficient use of available vaccines.

ATV D-TEAM Institute of Immunology, Moscow, Russia.

\section{CHEMICAL COMPOSITION}

Chromatographically purified capsular polysaccharide from Salmonella typhi (CP-Vi-antigen) is the main polysaccharide typhoid VIANVAC ${ }^{\circledR}$ vaccine component. CP-Vi-antigen is isolated by gel-filtration with use of most mild methods of treatment and lowered number of procedures with chemical agents involved. CP-Vi-antigen is being highly purified during manufacturing process. Protein and nucleic acids admixtures contaminating the main substance are strictly controlled (protein contamination $<1 \%$, nucleic acids contamination $<2 \%$ ). As a result vaccine final form contains chromatographically purified ac- 


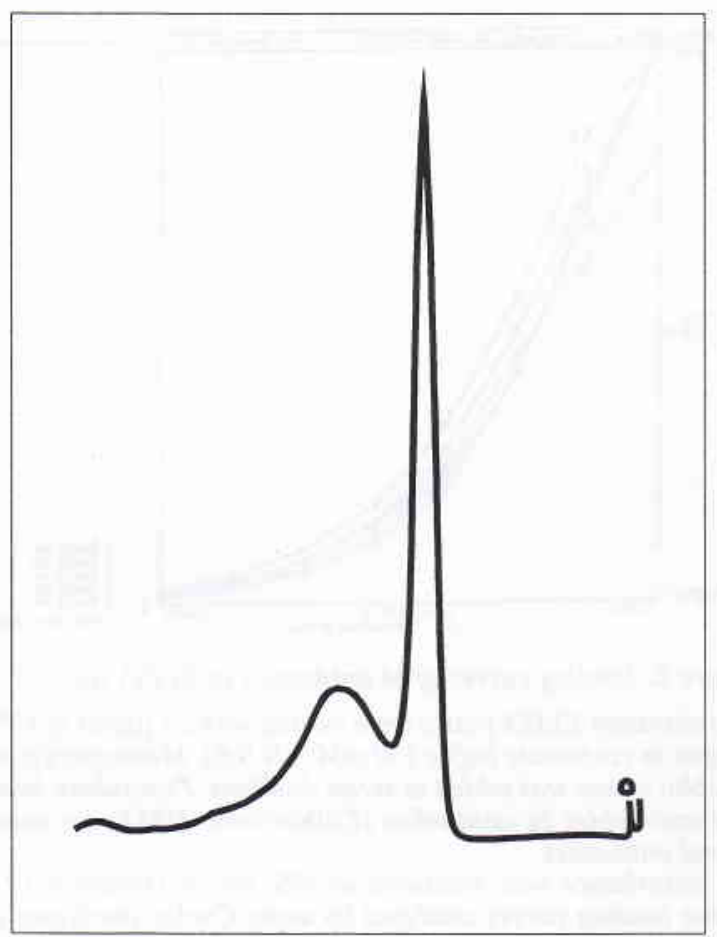

Figure 1. Gel filtration profile of $C P$-Vi-Antigen vaccine (lot 130 ) passing through Sepharose $4 B-C L$.

tive substance which can be chemically identified and analyzed.

$\mathrm{CP}-\mathrm{Vi}$-antigen is a non-toxic polysaccharide which represent linear polymer built of $\alpha(1-4)$-linked N,OAc galactouronic acid residues. Native CP-Vi-antigen molecules reach significant size. That's why during its production it is important to avoid its depolymerization i.e. its decay to small chains. Maximal high molecular and immunogenic fractions of CP-Vi-antigen are used in vaccine preparation. They appear as

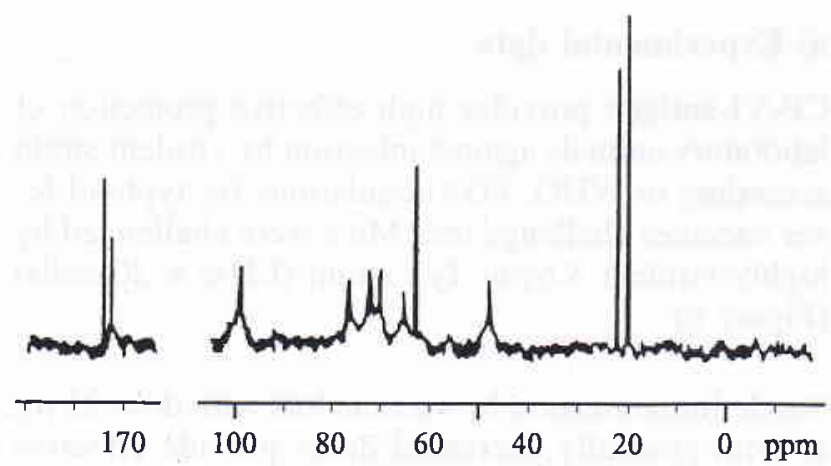

Figure $2 .{ }^{13} \mathrm{C}-\mathrm{NMR}$-spectrum of $\mathrm{CP}$-Vi-antigen from vaccine (lot 130) clear sharp peaks on the chromatograms of vaccine series (Figure 1).

At least $50 \%$ of the Vi-polysaccharide eluted from the column Sepharose CL-4B before a distribution constant $\mathrm{K}_{\mathrm{D}}-0.25$.

$\mathrm{CP}-\mathrm{Vi}$-antigen molecule structure (including most immunologically active $\mathrm{O}-\mathrm{Ac}-$ and $\mathrm{COO}^{-}$- groups) have been verified by NMR - spectroscopy (Figure 2).

Peak corresponded to immunodominant O-Ac group is determined under the $21 \mathrm{ppm}$.

We permanently control O-acetyl group content in preparation by NMR -spectroscopy or Hestrin technique. O-Acetyl group content for different lots of CP-Vi-antigen were no less than $2.0 \mu \mathrm{mol} / \mathrm{mg}$ and consist of $2.8 \mu \mathrm{mol} / \mathrm{mg}, 3.0 \mu \mathrm{mol} / \mathrm{mg}, 2.9 \mu \mathrm{mol} / \mathrm{mg}$ correspondingly for Lot 125, 127, 130.

\section{IMMUNOCHEMISTRY}

Nativity, functional activity of CP-Vi-antigenic determinants have been investigated by immunochemical methods.

Immunochemical identification of CP-Vi-antigen lots have been performed by Ouchterlony technique with $\mathrm{Vi}$ and $\mathrm{O}: 9$ monovalent serum (Figure 3).
1

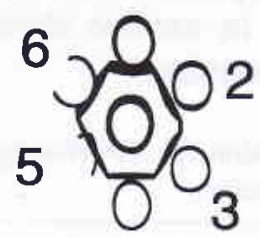

a)
4
Figure 3. Identification of the main component of the CP-Vi-vaccine antigen by the Ouchterlony technique. Central well was inoculated by a) mono-Vi serum $25 \mu \mathrm{l}$. b) mono-O:9 serum $25 \mu \mathrm{l}$.

well 1-2 Lot 125

well 3-4 Lot 127

well 5-6 Lot 129 


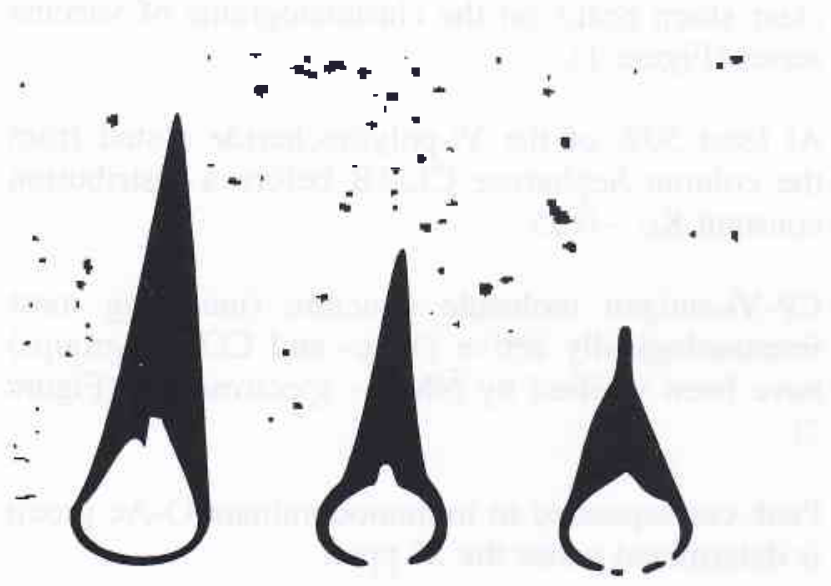

Figure 4. Determination of $C P$-Vi-antigen content in vaccine final form.

1 - Lot $125(50 \mu \mathrm{g} / \mathrm{ml})$

2 - Lot $125(25 \mu \mathrm{g} / \mathrm{ml})$

3 - Lot $125(12.5 \mu \mathrm{g} / \mathrm{ml})$

CP-Vi-antigen content in VIANVAC ${ }^{\circledR}$ final form have been studied by Rocket immunoelectrophoresis technique (Figure 4).

Serological activity of CP-Vi-antigen preparations were analyzed by inhibition specific haemagglutination reaction (IHA). CP-Vi-Antigen adsorbed erythrocytes and monospecific Vi-antiserum in concentration 4 SU (Diagnostic Pasteur, France) were used. Inhibition concentration varied from 0.1 to $5.0 \mu \mathrm{g} / \mathrm{ml}$ is presented in the Table 1.

Binding curves of $\mathrm{Vi}$ antibodies by solid phase adsorbed CP-Vi-antigen Lot's 125, 127 differ slightly in ELISA tests (Figure 5). The present data suggests that $\mathrm{CP}$-Vi-antigen lots used in vaccine show high and nearly equal serological activity.

Table 1. Inhibition point concentration for CP-Vi-antigen and Vi-antigen (Typhim-Vi vaccine)

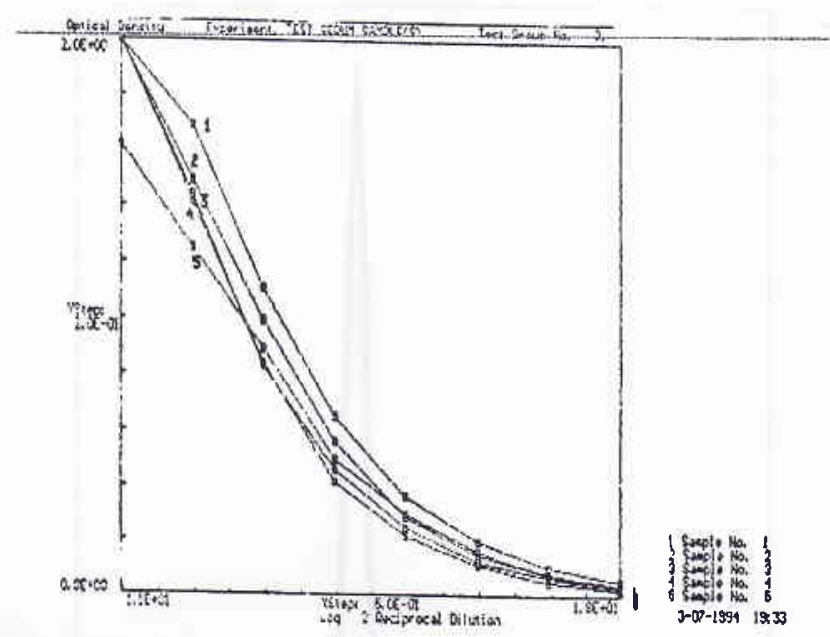

Figure 5. Binding curves of Vi antibodies in ELISA test.

Microtitration ELISA plates were coated with $25 \mu \mathrm{g} / \mathrm{ml}$ of $\mathrm{CP}-\mathrm{Vi}$ antigen in carbonate buffer $(50 \mathrm{mM}, \mathrm{pH}$ 9.6). Monospecific anti$V i$ rabbit serum was added in serial dilutions. Peroxidase-labeled goat anti-rabbit Ig antibodies (Calbiochem, USA) was used as second antibodies.

The absorbance was measured at $492 \mathrm{~nm}$ in Dynatech ELISA reader, binding curves analyzed by using Cyclop analyzing program.

Sample 1-2 Lot 125

Sample 3, 4, 5 Lot 127

\section{PROTECTIVE \& IMMUNOGENIC PROPER- TIES}

Vi-Antigen (an antigen of virulence) is a very important protective antigen for typhoid fever. It protects animals against typhoid fever infection in model experiments, induces anti-Vi antibody response in humans and animals, triggers off the complement system and macrophages. Vi-Antigen plays an important role in pathogenesis of typhoid fever especially in severe forms course. High immunogenic properties of CP-VI-antigen vaccine are stipulated by modern technology of its production: it allows to obtain CP$\mathrm{Vi}$-antigen in non-denatured form.

\section{a) Experimental data}

CP-VI-antigen provides high effective protection of laboratory animals against infection by virulent strain according to WHO, FDA regulations for typhoid fever vaccines challenge test. Mice were challenged by highly-virulent S.typhi Ty 2 strain $\left(\mathrm{LD}_{50}<20\right.$ cells) (Figure 6).

Single immunization by vaccine lots with dose $25 \mu \mathrm{g}$ as with gradually decreased doses provide effective $100 \%$ protection against typhoid fever infection according to vaccine testing protocol (Table 2). 


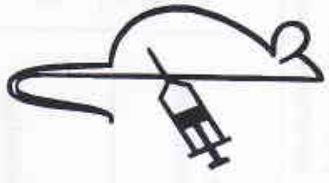

i/p Immunization CP-Vi-antigen vaccine lots

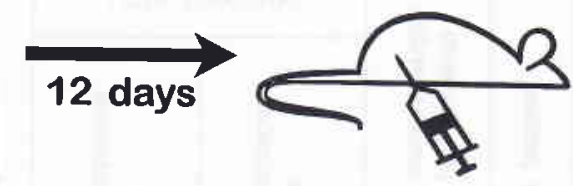

i/p Challenge S.typhi Ty2 strain 1000 cells in $5 \%$ mucin

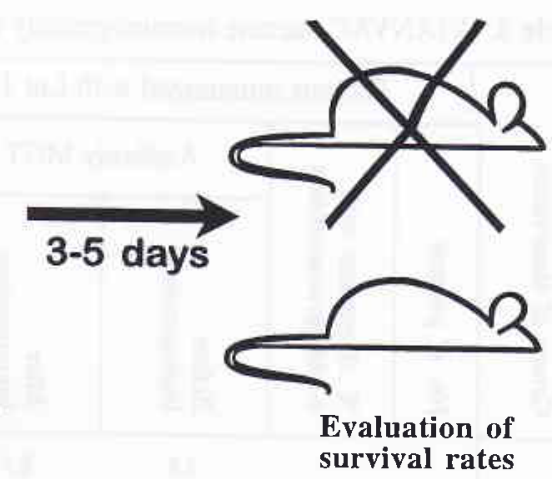

Figure 6. Experimental protocol of the CP-Vi antigen protection in the challenge test.

Tabel 2. Protection rates after single immunization of mice with CP-Vi antigen (VIANVAC ${ }^{\circledR}$ Lot \#125, 128, 130) and Wyeth whole cell vaccine and challenge with S.typhi Ty2.

\begin{tabular}{|c|c|c|c|c|c|c|c|}
\hline $\begin{array}{l}\text { Immuniza- } \\
\text { tion dose } \\
\text { for vaccine } \\
\quad(\mu \mathrm{g})\end{array}$ & $\begin{array}{l}\text { Part of } \\
\text { human } \\
\text { dose }\end{array}$ & $\begin{array}{c}\text { Survival of } \\
\text { mice } \\
\text { per group } \\
\text { immunized } \\
\text { with } \\
\text { VI-vaccine } \\
\text { VIANVAC } \\
\text { Lot } 125\end{array}$ & $\begin{array}{c}\text { Survival of } \\
\text { mice } \\
\text { per group } \\
\text { immunized } \\
\text { with } \\
\text { VI-vaccine } \\
\text { VIANVAC } \\
\text { Lot } 128\end{array}$ & $\begin{array}{c}\text { Survival of } \\
\text { mice } \\
\text { per group } \\
\text { immunized } \\
\text { with } \\
\text { VI-vaccine } \\
\text { VIANVAC } \\
\text { Lot } 130\end{array}$ & $\begin{array}{l}\text { Immuniza- } \\
\text { tion dose } \\
\text { for vaccine } \\
\text { (protective } \\
\text { units USP) }\end{array}$ & $\begin{array}{l}\text { Part of } \\
\text { humanan } \\
\text { dose }\end{array}$ & $\begin{array}{l}\text { Survival of } \\
\text { mice per group } \\
\text { immunized } \\
\text { with Typhoid } \\
\text { vaccine USP } \\
\text { Wyeth Whole } \\
\text { cell vaccine } \\
\text { Lot } 4928282\end{array}$ \\
\hline 25 & $1 / 10$ & $10 / 10$ & $10 / 10$ & $10 / 10$ & $2 u$ & $1 / 4$ & $10 / 10$ \\
\hline 2.5 & $1 / 50$ & $10 / 10$ & $10 / 10$ & $10 / 10$ & $1 \mathrm{u}$ & $1 / 8$ & $10 / 10$ \\
\hline 0.5 & $1 / 250$ & $10 / 10$ & $10 / 10$ & $10 / 10$ & $0.5 \mathrm{u}$ & $1 / 16$ & $10 / 10$ \\
\hline 0.02 & $1 / 1250$ & $10 / 10$ & $10 / 10$ & $10 / 10$ & $0.25 \mathrm{u}$ & $1 / 32$ & $7 / 10$ \\
\hline 0.004 & $1 / 6250$ & $8 / 10$ & $10 / 10$ & $7 / 10$ & $0.125 \mathrm{u}$ & $1 / 64$ & $5 / 10$ \\
\hline Control & & $0 / 10$ & $0 / 10$ & $0 / 10$ & & & $0 / 10$ \\
\hline
\end{tabular}

Protective activity was compared with USP typhoid vaccine standard and showed that protective potential of CP-Vi-antigen vaccine may be evaluated in typhoid protective units USP. Primary Vi-specific immune response on mice was registered after immunization (CBAxC57B1/6)F1 mice with lots of CP-Viantigen (Figure 7).

High levels of anti-Vi antibodies were detected after immunization of with $25 \mu \mathrm{g}$ (human dose), $5 \mu \mathrm{g}$ (1/5

\begin{tabular}{|c|c|c|c|c|c|}
\hline \multirow{3}{*}{$\begin{array}{c}\text { Immunisation } \\
\text { dose, } \\
\mu \mathrm{g}\end{array}$} & \multirow[t]{3}{*}{ Immunogen } & \multicolumn{4}{|c|}{$\begin{array}{l}\text { ELISA-titer anti-Vi IgG-antibodie } \\
\text { on day } 11\end{array}$} \\
\hline & & $\top$ & & & $\Gamma$ \\
\hline & & 4000 & 8000 & 16000 & 32000 \\
\hline 1 & LOT 129 & : & & & \\
\hline 5 & LOT 129 & & & & \\
\hline 25 & LOT 129 & & & & \\
\hline 1 & LOT 130 & & & & \\
\hline 20 & LOT 130 & & & & \\
\hline 25 & LOT 130 & & & & \\
\hline
\end{tabular}

Figure 7. Primary Vi-specific immune response after immunization with CP-Vi antigen Lot's 129 and 130. human dose), $1 \mu \mathrm{g}$ (1/25 human dose). Two most important in view of typhoid bacteria neutralization classes of anti- $\mathrm{Vi}$ antibodies -IgG and -IgM are presented in serum after vaccination.

Induction of delayed-type hypersensitivity (DTH) in foodpad-swelling test was registered after immunization with CP-Vi-antigen. DTH induction by Vi-antigen depends on immunization dose. Therefore the data obtained indicated activation of humoral as well as cell part of immunity.

\section{b) Clinical data}

\section{Double-blind randomized study}

Similar to analogous preparations CP-Vi-antigen induced strong humoral immune response and seroconversion.

Under the double-blind randomized volunteer study seroconversion was evaluated by traditional indirect haemagglutination test (IHA). 
Table 3. VIANVAC vaccine immunogenicity under double-blind randomized study

\begin{tabular}{|c|c|c|c|c|c|c|c|c|c|c|c|c|}
\hline \multirow{3}{*}{ 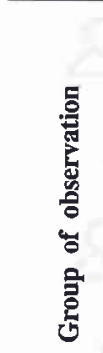 } & \multicolumn{4}{|c|}{ Persons immunized with Lot 127} & \multicolumn{4}{|c|}{ Persons immunized with Lot 128} & \multicolumn{4}{|c|}{ Placebo group } \\
\hline & \multirow[b]{2}{*}{ 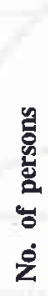 } & \multirow{2}{*}{ 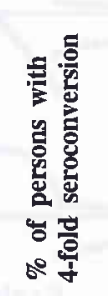 } & \multicolumn{2}{|c|}{ Antibody MGT } & \multirow[b]{2}{*}{ 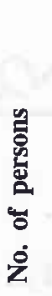 } & \multirow{2}{*}{ 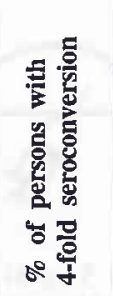 } & \multicolumn{2}{|c|}{ Antibody MGT } & \multirow[b]{2}{*}{ 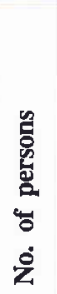 } & \multirow{2}{*}{ 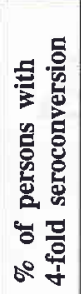 } & \multicolumn{2}{|c|}{ Antibody MGT } \\
\hline & & & 总 & 总总营 & & & 总 & 总 & & & 总 & 点兽 \\
\hline \multirow[t]{2}{*}{ Total } & & & 2.6 & 5.1 & & & 2.5 & 5.4 & & & 2.5 & 2.7 \\
\hline & 74 & $71.6 \pm 5.2$ & $1: 8 \div 1: 4.6$ & $1: 39 \div 1: 30$ & 76 & $78.9 \pm 4.7$ & $1: 7.5+1: 4.3$ & $1: 56 \div 1: 32$ & 68 & 一 & $1: 7.5 \div 1: 4.3$ & $1: 8.6 \div 1: 4.9$ \\
\hline $\begin{array}{l}\text { Sero- } \\
\text { negative }\end{array}$ & & & - & 5.1 & & & - & 4.8 & & & - & 0.3 \\
\hline persons & 14 & 100.0 & 0 & $1: 52 \div 1: 22.6$ & 18 & 100.0 & 0 & $1: 42 \div 1: 18.4$ & 13 & - & 0 & $(0)$ \\
\hline $\begin{array}{l}\text { Sero- } \\
\text { positive }\end{array}$ & & & 3.2 & 5.1 & & & 3.2 & 5.7 & & & 3.1 & 3.2 \\
\hline persons & 60 & $65.0 \pm 6.2$ & $1: 10.6+1: 8$ & $1: 39 \div 1: 30$ & 58 & $72.4 \pm 5.9$ & $1: 10.6 \div 1: 8$ & $1: 69 \div 1: 39$ & 55 & - & $1: 9.8 \div 1: 7.5$ & $1: 10.6 \div 1: 8$ \\
\hline
\end{tabular}

* anti-Vi-antibodies were determined by IHA-test with Vi-antigen coated erythrocytes.

According to data presented in the Table 3, four-fold seroconversion was observed to occur in $100 \%$ of all seronegative persons immunized with VIANVAC vaccine one month after vaccination; whereas this in-
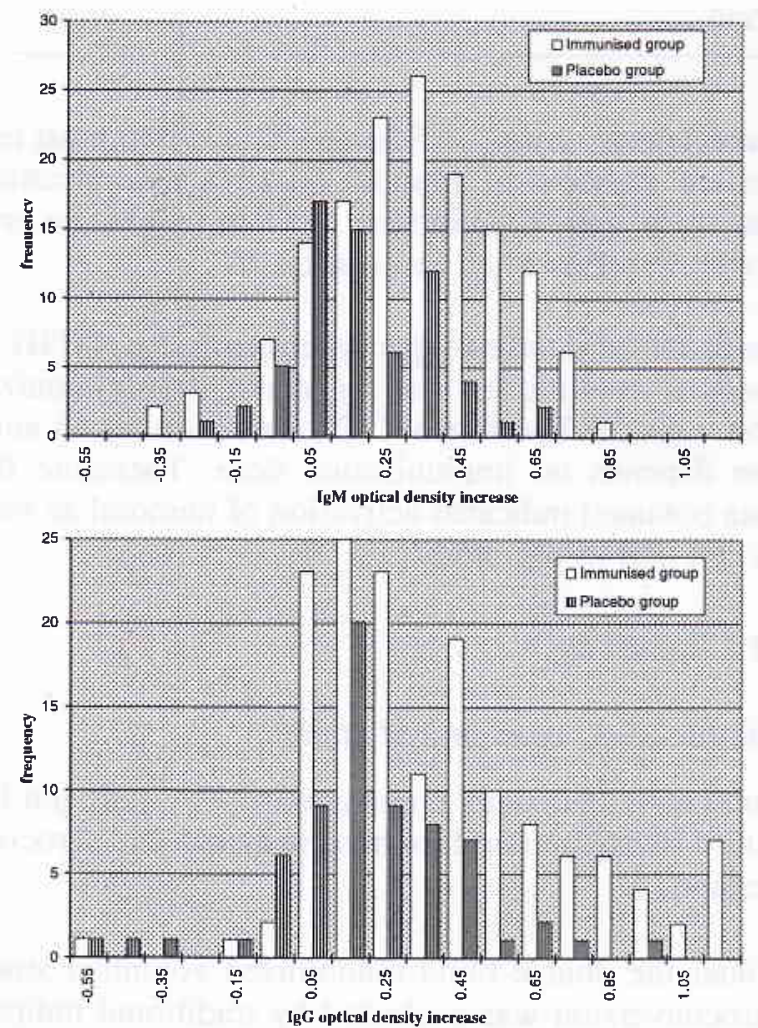

dex was somewhat lower in seropositive persons. So, this index value was $65 \%$ in persons immunized with VIANVAC, lot 127 and $72.4 \%$ in persons immunized with lot 128 , but the difference between these value was found to be statistically unreliable $(p>0.05)$.

Summary index value of four-fold seroconversions (independent upon initial immune background) in the groups of persons immunized with VIANVAC, lot 127 and lot 128 was $71.6 \%$ and $78.9 \%$ respectively, and the difference between these value was also statistically unreliable $(p>0.05)$.

Levels of postimmunization antibodies were thoroughly studied by ELISA-technique. CP-Vi-antigen induced statistically significant rises $(p>0.05) \quad \mathrm{IgG}$

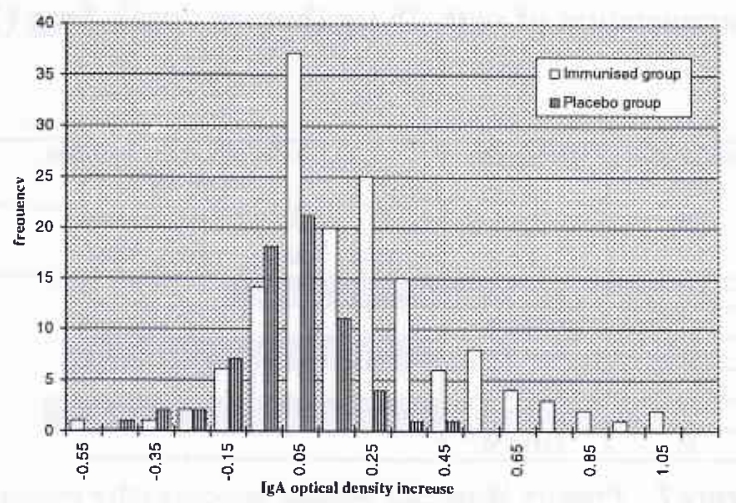

Figure 8. Postimmunization IgG, IgM, IgA antibodies levels in volunteers immunized by CP-Vi antigen. 
and $\operatorname{IgM}$ and even $\operatorname{IgA} \mathrm{Vi}$-specific antibody levels (Figure 8).

Mean of optical density $\mathrm{OD}_{492}$ increase for $\mathrm{IgG}$ anti$\mathrm{Vi}$ antibodies in immunized persons was $0.33 \pm 0.11$ versus placebo group persons $0.14 \pm 0.06$; for $\mathrm{IgM}$ anti-Vi antibodies was $0.28 \pm 0.06$ versus $0.16 \pm 0.05$; for IgA anti-Vi antibodies $0.15 \pm 0.06$ versus $0.03 \pm 0.02$.

It should be stressed that $\operatorname{IgA}$ specific antibodies is well-known mechanism of mucosal immunity induction.

\section{Immunization under typhoid fever epidemy in $T a$ - jikistan}

Organized contingent of frontier service RF in Republic Tajikistan have been immunized by VIANVAC(1) vaccine based on CP-Vi-antigen in March 1997 (18362 persons).

Immunization caused significant decrease of typhoid fever morbidit:' according to 7-month supervision data (Figure 9).

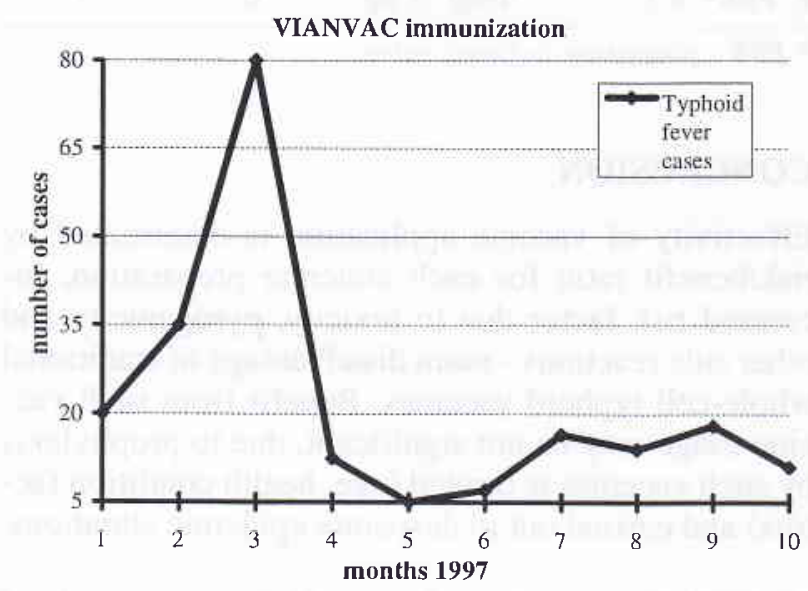

Figure 9. Incidence of typhoid fever after VIANVAC immunization under Tajik epidemic.

Incidence rate of infection is greatly decreased to 2.77 cases per 1000 among immunized person. In contrast incidence rate among non-immunized organized contingents varied from 10 to 12 cases per 1000 .

\section{SAFETY}

VIANVAC(1) is the vaccine with high safety profile. Chromatography grade of Vi-antigen and detailed control of the preparation provides its good tolerance.

\section{a) Experimental data}

Occasionally some redness and swelling may occur at the site of injection. Pain sensation registered in $30-35 \%$ of vaccinated persons.

Examination of the $\mathrm{CP}-\mathrm{Vi}$-antigen general toxicity in rodents: (CBAxC57Bl/6)F1 mice, Vistar rats, guinea pigs and Shinshilla rabbits allows us to make a conclusion that CP-Vi-Antigen has an extremely wide therapeutical index. The dose of $35 \mathrm{mg} / \mathrm{kg}$ which is 100,000 times more than the equivalent vaccinating dose of $0.35 \mu \mathrm{g} / \mathrm{kg}$ ( $25 \mu \mathrm{g}$ per $70 \mathrm{~kg}$ human body weight) very well tolerated by animals after the injection, and does not cause any changes in behavior, water and food consumption, increase of body and inner organs weight. The further investigation of the preparation in order to determine CP-Vi-Antigen LD 50 was unreasonable due to the absence of any noticeable toxic effect after such a considerable $(100,000$ times $)$ overdose of the vaccine.

To evaluate chronic toxicity CP-Vi-antigen was injected to rabbits repeatedly (10 times) during the day in a 8 times overdose. Any structural or functional changes proved by haematological, biochemical, ophtalmological, and pathomorphological investigations were not found except for hyperemia at the place of injections in some rabbits.

CP-Vi-antigen Lots met WHO requirements for pyrogenicity of polysaccharide typhoid vaccine. Threshold apyrogenic dose for vaccine Lots is significantly higher than WHO approved parameter (Table 4).

Table 4. CP-Vi antigen pyrogenicity.

\begin{tabular}{lccc}
\hline $\begin{array}{l}\text { Vi-Vaccine } \\
\text { Lots }\end{array}$ & $\begin{array}{c}\text { Threshold apyro } \\
\text { genic dose }(\mu \mathrm{g} / \mathrm{ml}) \\
\text { per } 1 \mathrm{~kg} \text { rabbit } \\
\text { body weight }\end{array}$ & $\begin{array}{c}\text { Dose of } \\
\text { apyrogenic } \\
\text { immunization* } \\
(\mu \mathrm{g} / \mathrm{ml})\end{array}$ & $\begin{array}{c}\text { Human } \\
\text { dose } \\
(\mu \mathrm{g})\end{array}$ \\
\hline LOT 125 & 0.550 & 1100 & 25 \\
LOT 127 & 0.720 & 1440 & 2 \\
$\begin{array}{c}\text { WHO control } \\
\text { parameter }\end{array}$ & 0.025 & 50 & \\
\hline
\end{tabular}

* under dilution coefficient 1:2000

Presence of the bacterial endotoxins was evaluated additionally by deaths rates of $(\mathrm{CBAxC} 57 \mathrm{Bl} / 6) \mathrm{F} 1 \mathrm{fe}-$ male mice which were administered by dactinomycin in a dose of $15 \mu \mathrm{g}$ per mice with the body weight $20 \mathrm{~g}$. Lipopolysaccharide from E. coli OIII: B 4 (Sigma) 
Table 5. CP-Vi antigen and Vi antigen (Typhim-Vi vaccine) endotoxicity under dactinomycin test.

\begin{tabular}{|c|c|c|c|c|c|c|}
\hline \multirow{2}{*}{ NN } & \multirow{2}{*}{ Groups of Preparations } & \multirow{2}{*}{$\begin{array}{c}\text { Number } \\
\text { of } \\
\text { Animals }\end{array}$} & \multirow{2}{*}{$\begin{array}{c}\text { Dactinomycin } \\
\text { dose } \\
\mu \mathrm{g} / \mathrm{g}\end{array}$} & \multicolumn{2}{|c|}{ Doses } & \multirow{2}{*}{$\begin{array}{c}\text { Deaths } \\
\text { Percentage }\end{array}$} \\
\hline & & & & $\mu \mathrm{g} /$ mice & $\mu \mathrm{g} / \mathrm{kg}$ & \\
\hline 1 & Dactinomycin & 20 & 0.75 & - & - & 0 \\
\hline 2 & Dactinomycin + solvent & 20 & 0.75 & $0.2(\mathrm{ml})$ & - & 0 \\
\hline 3 & Dactinomycin + CP-Vi-VACCINE & 20 & 0.75 & 2.5 & 125 & 100 \\
\hline 4 & Dactinomycin + CP-Vi-VACCINE & 20 & 0.75 & 2.0 & 100 & 80 \\
\hline 5 & Dactinomycin + CP-Vi-VACCINE & 20 & 0.75 & 1.5 & 75 & 40 \\
\hline 6 & Dactinomycin + Typhim-Vi & 20 & 0.75 & 2.5 & 125 & 100 \\
\hline 7 & Dactinomycin + Typhim-Vi & 20 & 0.75 & 2.0 & 100 & 100 \\
\hline 8 & Dactinomycin +Vi-Typhim & 20 & 0.75 & 1.5 & 75 & 40 \\
\hline 9 & Pactinimicint Lipopolysaccharide & 20 & 0.75 & 0.004 & 0.2 & 20 \\
\hline 10 & Dactinomycin + Lipopolysaccharide & 20 & 0.75 & 0.002 & 0.1 & 0 \\
\hline
\end{tabular}

was used as a positive control, while the PBS-phenolcontaining solvent for $\mathrm{CP}-\mathrm{Vi}$-antigen was used as negative control.

$\mathrm{CP}-\mathrm{Vi}$-antigen toxicity considering the degree of purification from bacterial endotoxins does not differ from Typhim-Vi vaccine (Table 5).

The possibility of the immediate allergic reactions induction attended by appearance of the homocytotropic antibodies in response to CP-Vi antigen injection was evaluated in guinea-pigs in systemic anaphylactic reaction .

Sensitization of the guinea-pigs with 230-250 g body weight was carried out according to the optimal allergization determination scheme and estimation of the reaction was made according to accepted 4-grade system registering (Table 6).

In conducted experiments with one or two sensitizing doses of the preparation the anaphylactic properties of CP-Vi antigen were not discovered.

\section{b) Clinical data}

Experimental and clinical data provide direct evidence that Vi-vaccine based on CP-Vi antigen is a well-tolerated preparation.

Low-level of adverse reactions under double-blind control clinical trials were registered. Systemic reactions: myalgias, allergic complications were absent. This complications are typical after immunization with whole-cell typhoid vaccine. Such general reactions as headache, moderate temperature rise $37.6^{\circ} \mathrm{C}$ $-<38.5^{\circ} \mathrm{C}$ are registered correspondingly in $3-4 \%$ and $1.3 \%$ of cases.
Table 6. Sensitization of the guinea-pigs by Vi-VACCINE.

\begin{tabular}{|c|c|c|c|}
\hline Sensitization & Challenge & $\begin{array}{c}\text { Anaphyl- } \\
\text { actic } \\
\text { Index }\end{array}$ & $\begin{array}{c}\text { Number } \\
\text { of } \\
\text { Animals }\end{array}$ \\
\hline $\begin{array}{l}\text { 1. Vi-VACCINE, } \\
5 \mu \mathrm{g} \times 3\end{array}$ & Vi-ag $75 \mu \mathrm{g}$ & 0 & 8 \\
\hline $\begin{array}{l}\text { 2. Vi-VACCINE, } \\
25 \mu \mathrm{g} \times 3\end{array}$ & Vi-ag $75 \mu \mathrm{g}$ & 0 & 8 \\
\hline 4. $\mathrm{PBS}^{*}, \mathrm{x} 3$ & Vi-ag $75 \mu \mathrm{g}$ & 0 & 2 \\
\hline
\end{tabular}

* PBS - phosphate-buffered saline

\section{CONCLUSION}

Effectivity of vaccine application is determined by risk/benefit ratio for each concrete preparation. Increased risk factor due to toxicity, pyrogenicity and other side reactions - main disadvantage of traditional whole-cell typhoid vaccines. Benefit from such vaccine usage may be not significant, due to prophylaxis by such vaccines is limited (age, health condition factors) and carried out in desperate epidemic situations.

VIANVAC - new formulation of Vi-antigen typhoid vaccine seriously differs from predecessors. This Viantigen vaccine has fully controlled chemical structure and immunogenic characteristics based on chromatography grade quality reliable. Factor risk decreasing removes risk/benefit ratio in favor of the last. It make justify to use VIANVAC for mass immunization adults and children over 5 years e.a. widespread prophylaxis of typhoid fever. 